\title{
CITRA PEREMPUAN DALAM DONGENG-DONGENG DAERAH NTT
}

\author{
Yuliana Jetia Moon ${ }^{1}$ \\ Antonius Nesi ${ }^{2}$ \\ ${ }_{1,2}$ Program Studi Pendidikan Bahasa dan Sastra Indonesia \\ Universitas Katolik Indonesia St. Paulus \\ J1. Jend. A. Yani 10, Ruteng, Flores, NTT \\ email: yulianajetiamoon@gmail.com
}

\begin{abstract}
Abstrak
Dongeng adalah warisan budaya lisan masyarakat. Budaya lisan diwariskan secara turun-temurun melalui tuturan lisan. Tuturan lisan, termasuk dongeng, merupakan perwakilan cara pandang, ajaran, dan keyakinan masyarakat yang menciptakannya. Tokoh-tokoh di dalam dongeng dikisahkan sedemikian rupa sehingga tergambar citra tokoh yang merepresentasikan cara pandang, kebiasaan, dan keyakinan masyarakat pemiliknya. Sehubungan dengan itu, penelitian ini bertujuan untuk memerikan citra perempuan dalam dongeng-dongeng NTT.Dalam pengumpulan data digunakan metode studi dokumen, teknik catat. Analisis data ditempuh dengan teknik analisis hermeneutik. Berdasarkan hasil analisis data diidentifikasi 4 (empat) jenis citra perempuan yang tergambar dalam dongeng-dongeng NTT, yakni (1) citra perempuan yang berkaitan dengan dirinya sendiri, (2) citra perempuan yang berkaitan dengan laki-laki, (3) citra perempuan yang berkaitan perempuan lainnya, dan (4) citra perempuan yang berkaitan dengan masyarakat.
\end{abstract}

Kata kunci: tradisi lisan, dongeng NTT, citra perempuan

\section{Pendahuluan}

Sejak dahulu kala, perempuan menjadi tokoh yang banyak digunakan dalam dongeng. Tokoh-tokoh perempuan itu juga hadir dalam dongeng-dongeng Nusantara. Hal itu terbaca jelas, misalnya, dalam dongeng "Asal Mula Padi" yang menampilkan tokoh Dewi Sri, legenda "Tangkuban Perahu" yang menampilkan tokoh Dayang Sumbi, tokoh Tujuh Bidadari dari Sumatera Utara dalam legenda "Danau Toba", Putri Aji Tatin dalam legenda "Asal Mula Balik Papan", dan lain-lain. Pada dongeng-dongeng tersebut, para tokoh perempuan ditampilkan secara khas melalui narasi dan dialog, yang dibingkai dalam unsur-unsur intrinsik dan ekstrinsik.

Penampilan tokoh-tokoh perempuan sebagaimana dikisahkan di dalam kebanyakan dongeng Nusantara tidak dapat ditampik sebagai cerminan budaya. Hal itu disebabkan tokoh perempuan yang diciptakan dalam dongeng mewakili cara pandang masyarakat terhadap keyakinan akan nilai-nilai luhur, terutama yang berkaitan dengan citra perempuan pada masyarakat penganutnya. Pada gilirannya, cara pandang masyarakat terhadap perempuan dapat diakui secara kolektif, termasuk pemosisian perempuan dalam masyarakat itu, peran perempuan dalam kehidupan sosial budaya pada masyarakat itu, dan lain-lain. Jika demikian, citra perempuan dalam dongeng menjadi urgen untuk dikaji secara ilmiah.

Dalam Kamus Besar Bahasa Indonesia (KBBI), citra dibatasi sebagai gambaran yang dimiliki orang mengenai pribadi (KBBI, 2008). Dalam kaitan dengan citra perempuan dalam dongeng, Abrams (Sofia, 2009) mengemukakan bahwa citra merupakan sebuah gambaran pengalaman indera yang diungkapkan lewat katakata, gambaran berbagai pengalaman sensoris yang dibangkitkan oleh kata-kata. Sementara itu, pencitraan merupakan kumpulan citra (the collection of image), yang lazim digunakan untuk melukiskan objek dan kualitas tanggapan indera yang dipergunakan dalam karya sastra, baik dengan deskripsi harafiah maupun kias (metaforis). Citra dan perempuan adalah dua kata yang secara sederhana dapat diartikan sebagai gambaran tentang pribadi dan kepribadian perempuan, baik yang ditampilkan oleh perempuan itu sendiri maupun yang ditampilkan oleh pihak lain. Pihak lain dalam hal ini, bisa tokoh lain atau monolog penulis.Sejalan konsep tersebut, citra perempuan, menurut Sugihastuti (2000), ialah gambaran tentang peran perempuan dalam kehidupan sosialnya. Hal itu sejalan dengan Walby (2011) yang mengungkapkan bahwa 
ketidaksetaraan gender atau perempuan secara subordinat yang terjadi pada masyarakat tidak semata-mata terjadi pada saat ini tetapi telah terkonstruksi mapan pada masyarakat lokal jaman dulu. Lebih lanjut, Walby (2011) menguraikan bahwa setelah kondisi masyarakat lokal yang menenpatkan perempuan secara subordinat maka akan terjadi pengsubordinatan posisi perempuan dalam sistem ekonomi, politik, dan peran sosial.

Dalam kajian-kajian mengenai tradisi, tradisi lisan selalu disamakan dengan folklor lisan. Menurut Sudikan (2013), genre folklor yang termasuk ke dalam kelompok lisan, yaitu (a) ragam tutur rakyat seperti logat, julukan, dan gelar kebangsawanan, (2) ungkapan tradisional, seperti peribahasa, pepatah, dan pameo, (3) pertanyaan tradisional seperti teka-teki, (4) puisi rakyat seperti pantun, gurindam, dan syair, dan (5) cerita prosa rakyat seperti mite, legenda, dan dongeng. Pada hakikatnya, dongeng merupakan cerita yang tidak benar-benar terjadi, terutama tentang kejadian zaman dahulu yang aneh-aneh (KBBI, 2008). Dari kesejatiannya itu, dongeng dikategorikan sebagai prosa rakyat yang bersifat tradisional dan pralogis. Hal ini sejalan dengan Danandjaja (2015) yang menyatakan bahwa pada umumnya prosa rakyat memiliki ciri pengenal, yaitu, (a) penyebaran dan pewarisannya bersifat lisan; (b) bersifat tradisional; (c) eksis dalam versi berbeda; (d) bersifat anonim dan pralogis, (e) bermanfaat dalam kehidupan bersama, dan $(\mathrm{g})$ bersifat polos dan lugu.

Meskipun bersifat tradisional dan pralogis, dongeng sebagai warisan lisan suatu masyarakat menarik untuk dikaji secara ilmiah. Hal itu terutama dilatari kenyataan bahwa di lingkungan desa ataupun perkotaan di seluruh Nusantara, warisan lisan, sebagaimana halnya dongeng, dipandang mengandung nilai-nilai hidup bersama berupa kebajikan moral dan pranata adat, yang pada gilirannya menciptakan dan mengabadikan keselarasan hidup antara manusia, lingkungan, dan Sang Pencipta (periksa Forshee, 2006; Duija, 2005). Jika demikian, dongeng berpotensi melahirkan kebijaksanaan (kearifan) karena di dalamnya dimuat aneka nilai yang dapat dijadikan sebagai pedoman dalam kehidupan sosial bermasyarakat.

Aerne dan Thomson (Danandjaja, 2015) membagi dongeng menjadi 3 jenis. Pertama, dongeng binatang atau fabel, yaitu sebuah dongeng yang di dalamnya dikisahkan mengenai perbuatan baik atau buruknya binatang. Di dalam fabel tokoh binatang berperilaku seperti manusia. Hal tersebut menganalogikan budi pekerti manusia. Buaya dan kancil merupakan salah satu contoh dongeng binatang yang berkarakter licik dan cerdik. Kedua, dongeng biasa, yaitu dongeng yang menceritakan tentang tokoh baik suka maupun duka, seperti dongeng bawang merah dan bawang putih. Ketiga, dongeng lelucon yaitu dongeng yang berisikan cerita lucu tentang tokoh tertentu, misalnya si Kabayan dari Jawa Barat, Lebai Malang, Pak Pandir,dan Pak Belalang.Dalam penelitian ini peneliti memberi atensi pada dongeng-dongeng NTT yang di dalamnya dilibatkan tokoh-tokoh perempuan.

Dongeng yang dikonstruksikan oleh masyakat lokal jaman dulu merupakan gambaran konstruksi perempuan jaman dulu. Konstruksi perempuan dalam dongeng bisa memberi gambaran posisinya dalam sitem adat yang kemudian akan berdampak pada perannya dalam sistem ekonomi, politik, dan peran sosial.

Dalam kenyataannya, dongeng Indonesia pada umumnya menampilkan tokoh perempuan. Sebagai contoh, dongeng "Bawang Merah Bawang Putih", dongeng "Gadis Cilik dalam Kerangjang Buah", dongeng "Putri Keraton Negeri Seberang", dan lain-lain. Seiring hadirnya dongeng-dongeng tersebut, geliat kajian perihal citra perempuan dalam dongeng makin menggelora. Dongeng yang menempatkan perempuan sebagai tokoh, meskipun berwujud fiksi, tetap merupakan kearifan lokal yang patut dipelajari dan dikaji mengingat perannya yang 'melegenda' dalam masyarakat pemiliknya karena senantiasa diwariskan dari satu generasi ke generasi berikut (Ratna, 2011, bdk. Taum, 2011).

Dalam konteks dongeng NTT, Wonga dalam penelitian "Citra Perempuan dalam Kumpulan Cerita Rakyat Flores Timur Lamaholot" (2016) berhasil mendeskripsikan, antara lain, bahwa perlakuan yang diterima tokoh perempuan dari tokoh laki-laki dalam cerita rakyat Flores Timur Lamaholot dapat berdampak pada ditinggikannya atau direndahkannya kedudukan perempuan. Kedudukan tokoh perempuan akan ditinggikan ketika mereka berhadapan dengan saudara mereka karena mereka adalah anak perempuan satu-satunya yang disayangi. Kedudukan mereka akan direndahkan saat mereka berhadapan dengan laki-laki dari alam gaib yang ingin menikahi mereka dan sistem pembagian kerja yang tidak adil. Sementara itu, dari sisi peran gender tokoh perempuan dalam 
cerita rakyat Flores Timur Lamaholot dibagi menjadi dua peran yaitu peran domestik dan peran publik. Tokoh perempuan, dalam hal ini lebih dominan menjalankan peran domestik. Namun, di sisi lain juga terdapat tokoh perempuan yang menjalankan peran publik. Berbeda dari penelitian Wonga, dalam penelitian ini digunakan pendekatan feminisme dengan sumber data representatif dari dongeng-dongeng NTT.

Dalam kenyataannya, setiap entitas etnik di NTT memiliki banyak dongeng. Pelbagai dongeng yang ada di NTT tentu mengisahkan pula tentang perempuan. Tokoh perempuan seperti Nggerang dalam dongeng "Loke Nggerang" di Manggarai, tokoh Fit Lalan dalam dongeng "Bi Fit Lalan Apao Ume" di daerah TTU, dan lainlain, merupakan representasi 'citra perempuan' dalam dongeng-dongeng di NTT. Sehubungan dengan itu, dalam penelitian ini hendak diangkat digali secara lebih mendalam mengenai“citra perempuan dalam dongeng-dongeng NTT". Sehubungan dengan itu, rumusan masalah penelitian ini ialah apa sajakah citra perempuan yang digambarkan dalam dongeng-dongeng NTT? Sejalan dengan rumusan masalah, tujuan penelitian ini ialah untuk memerikan citra perempuan dalam dongeng-dongeng NTT.

\section{Metode Penelitian}

Penelilitian ini merupakan penelitian deskriptif kualitatif. Bodgan dan Taylor (dalam Soewadji, 2012:51) mengemukakan bahwa penelitian deskriptif kualitatif diartikan sebagai salah satu prosedur penelitian yang menghasilkan data deskriptif berupa ucapan atau tulisan dan perilaku orang-orang yang diamati. Sumber data penelitian ini adalah dongeng-dongeng yang diambil dari kabupaten-kabupaten yang ada di Provinsi NTT. Dongeng-dongeng yang diambil adalah mite, parabel, dan legenda. Selain itu dongeng yang dipilih adalah dongeng yang di dalamnya terdapat tokoh perempuan. Postulat dasar yang dibangun peneliti ialah bahwa kedudukan tokoh perempuan dalam dongeng memiliki peran cukup penting, entah sebagai tokoh utama ataupun tokoh tambahan yang memiliki dominasi kehadiran yang tinggi. Populasi penelitian ini adalah seluruh dongeng NTT. Sampel dongeng diambil dari setiap pulau di NTT. Pengambilan sampel dongeng akan dihentikan jika dalam analisis data, sumber data telah terpenuhi.

Metode pengumpulan data dalam penelitian ini adalah studi dokumen. Dalam studi dokumen peneliti mengoleksi berbagai dokumen yang berkaitan dengan topik penelitiannya. Dengan kata lain, dalam studi dokumen peneliti mengumpulkan berbagai informasi yang relevan dengan topik penelitiannya, baik untuk memperoleh maupun untuk menjelaskan data (Cresswel, 2010). Sejalan dengan metodenya, dalam penelitian ini digunakan teknik catat. Melalui teknik catat, peneliti mencatat bagianbagian yang relevan dengan topik penelitian ini (bdk. Sudaryanto, 2015).Prosedur pengumpulan data dalam penelitian ini adalah sebagai berikut. Pertama, peneliti mengoleksi dongeng-dongeng yang relevan dengan topik penelitian ini, yakni mite, parable, dan legenda. Kedua, peneliti membaca dengan cermat dongeng-dongeng yang telah dikoleksi. Ketiga, peneliti mencatat bagianbagian dari dongeng yang berhubungan dengan citra perempuan (periksa Sudaryanto, 2015) serta merujuk teori-teori yang relevan untuk mendukung tujuan penelitian.

Analisis data dalam penelitian ini menggunakan metode analisis hermeneutik. Prosedur analisis penelitian ini ialah sebagai berikut. Pertama, peneliti mengidentifikasi tokoh perempuan dalam dongeng. Kedua, peneliti mengklasifikasikan tokoh perempuan dalam dongeng berdasarkan kedudukannya di dalam masyarakat. Ketiga, peneliti mengidentifikasi citra perempuan dalam dongeng. Keempat, peneliti memaparkan, menafsirkan, dan menyimpulkan citra tokoh perempuan dalam dongeng. Prosedur ini analisis ini mengakomodasi hakikat analisis data hermeneutik dalam penelitian bahasa dan sastra (Nurgiyantoro 2007; periksa Cresswel, 2010).

\section{Hasil dan Pembahasan}

Dongeng yang dianalisis dalam penelitian ini berjumlah 7 (tujuh) dongeng yang dipilih secara representatif dari daerah-daerah NTT. Ketujuh dongeng itu adalah (1) Loke Nggerang (Manggarai), (2) Bete Dou No Mane Loro (Belu), (3) Nenek Wini, (Sumba), (4) Kisah Lona Kaka dan Lona Lara (Sumba), (5)Kisah Uto Bata (Flores Timur), (6) Bita Nahak No Bikuku (Belu),dan (7) Hera Alune (Rote Sabu). Dongeng- 
dongeng yang diteliti selanjutnya diurutkan dan diberi kode, yakni dongeng 1 s.d. 7 (kode D1 s.d. D7), diikuti judul dongeng (kode disingkat), kode daerah asal dongeng (disingkat), dan kode data yang diurutkan secara numerik. Kode data dalam penelitian ini dapat dilihat pada tabel berikut.

\section{Tabel 1 Kodifikasi data}

\begin{tabular}{lllll}
\hline No. & $\begin{array}{c}\text { Judul } \\
\text { Donngeng }\end{array}$ & Daerah & $\begin{array}{c}\text { Kode } \\
\text { Dongeng }\end{array}$ & $\begin{array}{c}\text { Kode } \\
\text { Data }\end{array}$ \\
\hline 1. & $\begin{array}{l}\text { Loke } \\
\text { Nggerang }\end{array}$ & Manggarai & D1/LN/M & $1 \ldots \mathrm{x}$ \\
\hline 2. & $\begin{array}{l}\text { Bete Dou No } \\
\text { Mane Loro }\end{array}$ & Belu & D2/BD/B & $1 \ldots \mathrm{x}$ \\
\hline 3. & Nenek Wini & Sumba & D3/NW/S & $1 \ldots \mathrm{x}$ \\
\hline 4. & $\begin{array}{l}\text { Kisah Lona } \\
\text { Kaka dan } \\
\text { Lona Lara }\end{array}$ & Sumba & $\mathrm{D} 4 / \mathrm{KLLL} / \mathrm{S}$ & $1 \ldots \mathrm{x}$ \\
\hline 5. & $\begin{array}{l}\text { Kisah Uto } \\
\text { Wata }\end{array}$ & Flores & $\mathrm{D} 5 / \mathrm{KUB} / \mathrm{FT}$ & $1 \ldots \mathrm{x}$ \\
\hline 6. & $\begin{array}{l}\text { Bita Nahak } \\
\text { No Bikuku }\end{array}$ & Belu & $\mathrm{D} 6 / \mathrm{BN} / \mathrm{B}$ & $1 \ldots \mathrm{x}$ \\
\hline 7. & $\begin{array}{l}\text { Hera Alune } \\
\text { (Rote Sabu) }\end{array}$ & Rote Sabu & $\mathrm{D} 7 / \mathrm{HA} / \mathrm{RS}$ & $1 \ldots \mathrm{x}$ \\
\hline
\end{tabular}

Berdasarkan hasil identifikasi data ditemukan 4 (empat) jenis citra perempuan yang terdapat dalam dongeng-dongeng NTT, yakni (1) citra perempuan yang berkaitan dengan dirinya sendiri, (2) citra perempuan yang berkaitan dengan laki-laki, dan (3)citra perempuan yang berkaitan perempuan lainnya, (4) citra perempuan yang berkaitan dengan masyarakat. Keempat citra perempuan yang ditemukan itu menggambarkan karakter pribadi perempuan dalam dongengdongeng NTT, baik dari sisi feminin maupun masukulin. Deksripsi hasil identifikasi diabstraksikan pada tabel berikut.

\section{Tabel 2 Hasil identifikasi dan klasifikasi data}

\begin{tabular}{lll}
\hline No. $\begin{array}{c}\text { Citra } \\
\text { Perempuan } \\
\text { dalam } \\
\text { Dongeng } \\
\text { NTT }\end{array}$ & Karakter Perempuan & $\begin{array}{c}\text { Jumlah } \\
\text { Data }\end{array}$ \\
\hline 1. & Citra & Mandiri, pekerja keras, \\
perempuan & pemberani, memiliki & \\
yang & keahlian/keterampilan & \\
berkaitan & tertentu, pribadi spiritual & \\
dengan & (makhluk religius), dan & \\
dirinya & mampu melakukan & \\
sendiri & kekerasan \\
\hline
\end{tabular}

\begin{tabular}{llll}
\hline 2. $\begin{array}{l}\text { Citra } \\
\text { perempuan } \\
\text { yang } \\
\text { berkaitan } \\
\text { dengan laki- } \\
\text { laki }\end{array}$ & $\begin{array}{l}\text { Tidak ingin dijajah secara } \\
\text { seksual atau mandiri } \\
\text { memilih pasangan, }\end{array}$ & 7 \\
takhluk pada saudara & $\begin{array}{l}\text { laki-laki, dan lemah dan } \\
\text { mudah memaafkan orang }\end{array}$ & \\
\hline 3. & $\begin{array}{l}\text { Citra } \\
\text { perempuan }\end{array}$ & $\begin{array}{l}\text { Bermusuhan, berselisih, } \\
\text { mang } \\
\text { berkaitan } \\
\text { perempuan } \\
\text { lainnya }\end{array}$ & $\begin{array}{l}\text { lain, memiliki rasa } \\
\text { empati }\end{array}$ \\
\hline $\begin{array}{l}\text { Citra } \\
\text { perempuan } \\
\text { yang } \\
\text { berkaitan } \\
\text { dengan } \\
\text { masyarakat }\end{array}$ & Bersikap \\
\hline
\end{tabular}

\section{Citra Perempuan yang Berkaitan dengan Dirinya Sendiri}

Dalam dongeng-dongeng NTT terdapat citra perempuan yang berkaitan dengan dirinya sendiri. Citra itu menunjukkan bahwa perempuan dalam dongeng NTT memiliki beberapa karakter yang khas, yakni (1) mandiri dan pekerja keras, (2) pemberani, (3) memiliki kekuatan, keahlian, atau keterampilan, dan (4) mampu melakukan kekerasan (membunuh). Data-data berikut menunjukkan bahwa tokoh perempuan dalam dongeng NTT memiliki citra sebagai pribadi yang mandiri dan pekerja keras.

(1) Seorang janda yang mengurusi pertanian dan perkebunan, serta peternakan ayam, kambing, dan babi warisan suaminya (D3/NW.S/1)

(2) Ia menjadi seorang penjaga kebun yang baik (D6/BN.B/1)

(3) ...mengambilair disungai, ...mencarikayubakardihutan (D4/KLLL.S/1)

(4) Uto wata membantu kakaknya di kebun, menanam padi, menyiapkan makanan, mengambil air, dan menenun(D5/KUW.FT/1)

(5) Hera Alune disuruh pula menjaga padi di sawah(D7/HA.RS/1)

Dalam budaya patriarki, sebagaimana juga dihayati oleh sebagian besar etnis di NTT, lakilaki memiliki peran sebagai kontrol utama di 
dalam masyarakat, sedangkan perempuan hanya memiliki sedikit pengaruh, baik secara ekonomi, sosial, politik, dan psikologi (Sakina dan Siti, 2017:71), termasuk profesi atau pekerjaan. Sebagai masyarakat agraris, semenjak dahulu mayoritas masyarakat NTT hidup sebagai petani (bercocok tanam). Profesi ini dijalani, baik oleh laki-laki maupun perempuan, meskipun ada beberapa jenis pekerjaan yang hanya bisa dilakukan oleh laki-laki, begitu sebaliknya, ada beberapa jenis pekerjaan yang hanya bisa dilakukan oleh perempuan NTT. Pekerjaan seperti memanjat pohon, membajak sawah, membangun rumah, dalam konteks masyarakat NTT merupakan jenis-jenis pekerjaan yang hanya dapat dilakukan oleh laki-laki. Sementara itu, beberapa jenis pekerjaan lain seperti mengayam tikar, menyulam benang, menenun dan memasak merupakan pekerjaan yang lazim dilakukan oleh para perempuan NTT. Kenyataan macam ini memberi cara pandang tersendiri bagi masyarakat NTT bahwa ada semacam 'pembagian jenis pekerjaan' untuk laki-laki dan perempuan (bdk. Sylvia, 2011).

Kenyataan sebagaimana dideskripsikan di atas tercermin dalam dongeng-dongeng NTT. Akan tetapi, di dalam dongeng-dongeng NTT perempuan justru dilukiskan dapat memerankan diri serupa laki-laki, yakni melakukan jenis-jenis pekerjaan yang dalam penghayatan budaya NTT pada umumnya jenis-jenis pekerjaan tersebut hanya dapat dilakukan laki-laki. Citra perempuan dalam dongeng-dongeng NTT justru memperlihatkan bahwa tokoh perempuan dihadirkan sebagai pribadi yang mandiri dan bekerja keras. Hal itu terlihat jelas pada data (D3/NW.S/1) s.d. (D7/HA.RS/1). Dalam data-data itu diperlihatkan bahwa tokoh perempuan dalam dongeng-dongeng NTT mampu melakukan pekerjaan-pekerjaan yang lazim dilakukan lakilaki seperti mengurusi pertanian, perkebunan, dan peternakan: mereka dapat menjaga kebun, menanam padi dan menjaganya, serentak pula melakukan melakukan jenis-jenis pekerjaan lain yang khas perempuan, yakni menyiapkan makanan, mengambil air, dan menenun.

Selain berkarakter mandiri dan pekerja keras, dalam dongeng-dongeng NTT juga diperlihatkan citra perempuan yang berkarakter pemberani. Perhatikan data-data berikut.
(1) "Lebih baik aku mati daripada menikah dengan laki-laki seperti dirimu," jawab Rueng tegas(D1/LN.M/1)

(2) PutriBeteDoumenjalanihidupnyaseorangd iridirumahkecilitu (D2/BD.B/1)

(3) Hera Alure melarikan diri... sendiri. Ia menumpangi perahu itu dan berlayar menuju negeri Sahu (D7/HA.RS/2)

Pada data (D1/LN.M/1), Nggerang, tokoh perempun dalam dongeng itu menolak untuk menikah dengan laki-laki yang dijodohkan orang tuanya. Dalam konteks masyarakat Manggarai zaman dahulu, jodoh yang diberikan orang tua, dari segi adat istiada setempat, harus diterima dengan lapang oleh perempuan. Akan tetapi, dalam dongeng itu justru dikisahkan bahwa Nggerang dengan sangat tegas menolak jodoh pemberian orang tua. Ia malah bertaruh "lebih baik aku mati daripada menikah dengan laki-laki itu". Kaitan antara penghayatan masyarakat terhadap budaya patriarki yang kental dengan penolakan Nggerang menunjukkan bahwa citra yang tergambar di dalam dirinya ialah perempuan pemberani. Dengan merujuk penelitian Moon, dkk., (2016) dapat dikatakan bahwa Nggerang dalam dongeng itu merupakan representasi dari identitas perempuan NTT pada umumnya yang menyadari diri sebagai pribadi, yang, meskipun memiliki pengetahuan terbatas tentang"gender", dari dalam dirinya terdapat sisi maskulinitas, yakni tabiat pemberani, terutama ketika menghadapi praktik budaya patriarki yang kadangkala terkesan "membelenggu" perempuan.

Hal yang sama dikisahkan juga di dalam dongeng Bete Dou, dongeng asal Belu, dan dongeng Hera Alure, dongeng asal Rote-Sabu, NTT. Bete Dou dan Hera Alure, judul sekaligus tokoh utama masing-masing dongeng itu, merupakan representasi perempuan NTT yang bertabiat pemberani. Jika di dalam dongeng Loke Nggerang asal Manggarai digambarkan citra perempuan bertabiat pemberani dalam menghadapi praktik budaya patriarkat ikhwal perkawinan, maka dongeng asal Belu dan RoteSabu ini menunjukkan keberanian perempuan dalam hal menjalani kehidupannya sendiri. Kedua tokoh perempuan itu, meskipun dikisahkan dalam dua dongeng yang berbeda asal dan latar, digambarkan dapat menjalani kehidupan mereka sendiri tanpa kehadiran laki-laki. Mereka dapat menjalankan perannya sendiri di dalam masyarakat, yakni peran domestik, dalam arti 
mereka jarang tampil di depan publik. Deskripsi ini hendak menegaskan bahwa kehadiran tokoh perempuan dalam dongeng NTT menempatkan perempuan sebagai pribadi pemberani yang dapat menjalankan kehidupannya sendiri ketika mereka terbelenggu dengan adanya praktik budaya patriarki (bdk. Wonga, 2016).

Selain memiliki citra pemberani, ketika berhadapan dengan dirinya sendiri, tokoh perempuan dalam dongeng-dongeng NTT digambarkan memiliki kekuatan, keahlian, atau keterampilan tertentu. Hal itu dibuktikan dengan adanya data-data berikut.

(1) Rueng memiliki ilmu gaib yang diwariskan Ibunya. Dia bisa menjadi apa saja yang diinginkan. Kadang dia berubah menjadi batu, pohon, atau binatang(D1/LN.M/2)

(2) Sesudah mengucapkan kata-kata tersebut di atas, laut menjadi pasang dan di hadapannya telah tersedia nasi kuning dan daging kuning. Dou menjalani hidupnya seorang diri di rumah kecil itu.(D6/BD.B/2)

(3) Saya bermaksud pergi kepada nenek di Aikepaka untuk belajar seni ikat motif, celup-celupan dan tenun-menenun. Relakanlah saya, Ayah dan Ibu, demi hari depanku. Hera Alure memanggil dewa laut dan dewa angina untuk menolongnya dalam perjalanan (D7/HA.RS/3)

(4) Setiap hari ia menyibukkan diri dengan menyulam dan mengayam tikar (D2/BD.B/2)

Tokoh Rueng, nama lain dari gadis Nggerang dalam dongeng Loke Nggerang asal Manggarai, dantokohDou dalam dongeng Bete Dou No Mane Loro dari Belu, sebagaimana dikutip pada data (D1/LN.M/2) dan (D6/BD.B/2) merupakan representasi tokoh perempuan dalam dongeng-dongeng NTT yang digambarkan memiliki ilmu gaib, sihir, atau mantra. Tokoh Rueng dikisahkan memiliki ilmu gaib yang diwariskan ibunya, yang notebene juga adalah perempuan; dia dapat berubah wujud, entah berwujud benda mati seperti batu dan tanah ataupun benda hidup seperti pohon dan binatang. Sementara itu, Dou dikisahkan memiliki kekuatan sihir verbal (kata-kata). Fenomena macam ini memang sulit diterima akal sehat. Meskipun demikian, di dalam analisis bahasa, kata-kata gaib atau mantra, cukup mendapatkan perhatian serius dari para linguis terutama bidang
Antropolinguistik (Linguistik Budaya) yang tentu saja berada di luar jangkauan penelitian ini (periksa Foley, 1997; Neonbasu, 2016).

Bukti bahwa tokoh perempuan dalam dongeng NTT memiliki keterampilan atau keahlian tertentu ditunjukkan pada data (D7/HA.RS/3) dan (D2/BD.B/2). Dalam kenyataannya, sebagian besar perempuan NTT memiliki keterampilan tenun-menenun dan mengayam tikar. Dalam konteks budaya ketimuran, Nordholt (1971), dalam sebuah studi etnografisnya menarasikan bahwa pada umumnya masyarakat Dawan NTT menghasilkan karya tenun motif menggunakan tangan sendiri dengan alat-alat tradisional. Bahan-bahan kain tenun motif diperoleh dan diolah dari alam. Mereka memanfaatkan tumbuhan kapas untuk merajut benang sendiri. Untuk menghasilkan warna-warni benang, mereka memanfaatkan bahan pewarna dari jenis tumbuhan tertentu yang diproses secara tradisional. Sementara itu, bila dilihat dari proses pengerjaannya dapat dikatakan bahwa waktu pengerjaannya sangat lama. Untuk menghasilkan satu kain tenun motif dibutuhkan waktu kurang lebih enam bulan, bahkan satu tahun.

Keterampilan menyulam dan menenun yang dimiliki para perempuan NTT patut diapresiasi sebagai bagian dari penghayatan lokal terutama dalam kaitan dengan penghargaan terhadap harkat dan martabat manusia. Hal ini sejalan dengan refleksi kritis Salu (2013) tentang sumbangsih kain tenun motif masyarakat. Salu (2013) menulis, “... keterampilan kerajinan tangan menenun para perempuan NTT yang diajarkan turun-temurun dari nenek moyang pada dasarnya menunjuk pada penghargaan manusia terhadap martabat diri dan sesamanya. "Kain dan selimut yang ditenun dan dipakai orang bertujuan untuk menutup aura, suatu penghargaan yang sangat tinggi terhadap martabat tubuh". Perempuan NTT juga memiliki keahlian atau keterampilan dalam mengayam tikar. Keuletan perempuan NTT terhadap jenisjenis pekerjaan itu pula yang diukir indah di dalam dongeng-dongeng NTT.

Di dalam dongeng-dongeng NTT teridentifikasi pula citra perempuan berkarakter spiritual (religius) di satu sisi, juga tokoh perempuan yang memiliki karakter mampu melakukan kekerasan sepert halnya membunuh di sisi lain. Dongeng Nene Wini (Sumba), Kisah Lona Kaka dan Lona Lara (Sumba), dan Bita 
Nahak No Bikuku (Belu) menggambarkan citra tersebut sebagaimana data-data.

(1) Ia pun menyepi dan bertemu dengan Marapu, yang berjanji akan menuntut balas atas sakit hatinya... Nenek Wini tetap meninggalkan kampung yang seluruh isinya kemudian berubah menjadi danau(D3/NW.S/2)

(2) LonaRara meloncat keluar dan menikamkan pisaunya berkali-kali kearah dada kakaknya (D4/KLLL.S/2)

(3) Parang diangkat dan diayunkan ke perut Bikuku. Perutnya terbelah menjadi dua bagian (D6/BN.B/3)

Pada data (D3/NW.S/2)diperlihatkan tokoh Nenek Wini sebagai perempuan yang memiliki karakter spiritual (religius). Dongeng itu mengisahkan bahwa tokoh Nenek Wini bertemu Marapu untuk memberi balas dendam kepada lawan yang telah membuatnya sakit hati. Hal itu tentu saja tidak dapat ditampik karena- meskipun tokoh yang dikisahkan adalah fiktif - pada dasarnya manusia adalah makhluk religius (homo religiosus) sekaligus makhluk egois.Dalam penghayatan agama tradisional masyarakat Sumba, Marapu diyakini sebagai wujud tertinggi, sebutan untuk Allah. Dongeng itu tentu hendak memperlihatkan sisi lain dari tokoh perempuan sebagai pribadi yang memiliki kerinduan spiritual dan keyakinan pada "Yang Ilahi", bahwa perasaan manusia (perempuan terus melekat pada Pencipta, yang lazim disebut Magholo//Marawi, yakni pencipta yang telah menciptakan segala sesuatu dari ketiadaan dan terus dengan perkasa mengikat semua ciptaan-Nya, bahkan dalam hal memberi balas dendam terhadap musuh, memberi pengampunan (rekonsiliasi), dan lain-lain (bdk. Neonbasu, 2016b).

Di sisi lain, pada (D4/KLLL.S/2 dan (D6/BN.B/3) yang dikutip dari dongeng Kisah Lona Kaka dan Lona Lara (Sumba) dan Bita Nahak No Bikuku (Belu) memperlihatkan bahwa tokoh perempuan di dalam dongeng-dongeng NTT memiliki sisi maskulin sebagai pribadi yang mampu melakukan kekerasan, bahkan dapat 'membunuh'. Sikap dan tindakan macam itu tentu saja dibingkai oleh konteks budaya masyarakat zaman dahulu kala tentang 'perang' atau 'bela diri'. Dalam dunia nyata, masyarakat NTT pada zaman dahulu, melibatkan perempuan dalam berbagai kegiatan perang (periksa Farram, 2004) terutama perang antarsuku dan terakhir perang melawan penjajah. Dalam beberapa catatan, misalnya, ditemukan bahwa adanya kalanya perempuan dalam perang dijadikan sebagai "mata-mata". Dongeng-dongeng NTT memperlihatkan keterlibatan para tokoh perempuan dalam hal perang, baik untuk mempertahankan diri sebagai pribadi, suku/klan, maupun dalam menghadapi pergulatan pribadinya terutama ketika berhadapan dengan budaya patriarki, musuh pribadi, atau bahkan dalam hal melawan tatanan adat istiadat yang membelenggu dirinya.

\section{Citra Perempuan yang Berkaitan dengan Laki- laki}

Dalam dongeng-dongeng NTT terdapat citra perempuan yang berkaitan dengan laki-laki. Citra ini memperlihatkan bahwa tokoh perempuan yang dihadirkan dalam dongeng-dongeng NTT memiliki beberapa karakter, yakni (1) tidak ingin dijajah secara seksual atau mandiri dalam memilih pasangan, (2) takhluk pada saudara laki-laki, dan (3) lemah dan mudah memaafkan orang lain. Dongeng NTT yang memperlihatkan perempuan yang tidak ingin dijajah secara seksual atau mandiri dalam memilih pasangan hidup dibuktikan dengan data-data berikut.

(1) Ketika suaminya meninggal, seorang penduduk kampung mencoba untuk memperistrinya. Namun karena rasa cinta yang dalam, Nenek Wini menolak pinangan tersebut.(D3/NW.S/3)

(2) "Engkau harus menikah denganku," kata Raja Bima.

"Lebih baik aku mati daripada menikah dengan laki-laki seperti dirimu," jawab Rueng tegas.(D1/LN.M/3)

(3) Bete Doupun siap untuk sehidup semati bersama Mane Loro. Akhirnya, keduanyapun menikah tanpa sepengetahuan orang tua mereka masingmasing. (D2/BD.B/2)

Tokoh Nene Wini dan Rueng yang dikisahkan dalam dongeng Nenek Wini (Sumba) danLoke Nggerang(Manggarai),sebagaimana ditunjukkan pada data (D3/NW.S/3) dan (D1/LN.M/3), merupakan dua tokoh perempuan dalam dongengdongeng NTT yang menolak untuk menikah dengan pasangan yang dijodohkan oleh orang tua, 
juga menolak dengan tegas untuk dijajah secara seksual.Meskipun suami Nene Wini telah meninggal dunia, di dalam dongeng itu dikisahkan bahwa ia masih mencintai suaminya yang telah meninggal. Justru itu, ia menolak untuk menerima pinangan dari orang lain. Hal ini pasti terkait erat dengan sistem monogami dan sangsi adat dalam sistem perkawinan patriarkat. Tokoh Rueng, di sisi lain, menolak pasangan yang dijodohkan kepadanya justru karena ia, Rueng, menyadari diri bahwa kepadanya dipaksakan seorang laki-laki yang tidak pernah ia duga dapat menjadi pasangan hidupnya. Ia pun menolak pasangan itu meskipun ia dinilai dapat melawan hukum adat. Sebagai konsekuensinya, sebagaimana dikisahkan dalam dongeng itu, ia akhirnya mati terbunuh karena persoalan jodoh, dan kulitnya itulah yang dapat dijadikan sebagai kulit gendang yang "bila ditabuh suaranya terdengan sampai ke Bima".

Sementara itu, tokoh Bete Dou yang dikisahkan dalam dongeng Bete Dou (Belu) justru memilih untuk menikah dengan kekasihnya tanpa sepengetahuan orang tuanya. Hal itu memperlihatkan bahwa Bete Dou adalah pribadi mandiri yang mampu menggunakan kehendak bebasnya untuk memilih pasangan hidupnya. Dalam budaya patriarki, keputusan Bete Dou pasti bertentangan dengan adat istiadat. Meskipun demikian, sebagaimana dikisahkan lebih lanjut di dalam dongeng itu, Bete Dou pada akhirnya diakui oleh masyarakat sebagai satu-satunya perempuan yang membawa perubahan dalam hal sistem perkawinan, yakni adanya kehendak bebas dari perempuan untuk dapat menentukan pasangan hidupnya. Hal itu juga terkait erat dengan posisi/status perempuan dalam penghayatan budaya masyarakat NTT pada umumnya.

Hasil studi Nesi (2018) memperlihatkan bahwa pada umumnya pranata budaya atau institusi kekerabatan dalam kelompok etnik NTT menempatkan perempuan sebagai "Mama", "Ibu" (bahasa Dawan:bife ainaf (dari kata bifel: perempuan dan bahasa Belu atau Flores Timur, Ina: Mama/Ibu). Predikat ini sungguh agung karena di situ tidak sekadar ditunjukkan mengenai hak perempuan atas "wilayah atau rumah" tetapi justru lewat predikat itu hendak dilukiskan mengenai kedudukan perempuan sebagai subjek sentral dalam praktik budaya, terutama ikhwal pelaksananaan ritus-ritus perkawinan adat pada hampir semua etnis NTT. Hal itu hendak memperlihatkan bahwa melalui bahasa sastra, dongeng-dongeng NTT dapat menggambarkan predikat perempuan sebagai pribadi yang bermartabat terutama bila dikaitkan dengan karakter diri mereka bahwa mereka tidak ingin dijajah seksual.

Selain dinarasikan bahwa tokoh perempuan tidak ingin dijajah secara seksual, dalam dalam tali-temalinya dengan relasi perempuan dan lakilaki, di dalam dongeng-dongeng NTT juga teridentifikasi citra perempuan yang memperlihatkan karakter diri mereka sebagai pribadi yang tunduk atau takluk pada saudara lakilaki dalam satu garis keturunan atau silsilah. Perhatikan data-data berikut.

(1) Ia hanya bisa pasrah untuk menerima hukuman dari kakaknya(D2/BD.B/3)

(2) Ia membantu kakaknya ...saudara Uto mendapat sebuah mimpi... laki-laki itu memintanya kepada saudara Uto untuk merelakan adik perempuannya... Uto ternyata mau menerima lamaran Nitung(D5/KUW.FT/2)

Pada data (D2/BD.B/3) dan (D5/KUW.FT/2) yang masing-masing dikutip dari dongeng Bete Dou (Belu) dan Kisah Uto Wata (Flores Timur) diperlihatkan dengan jelas bahwa tokoh perempuan dapat menerima dengan lapang perlakuan dari saudaranya (laki-laki). Narasi dalam kedua dongeng itu dibingkai oleh adanya kenyataan bahwa pada umumnya masyarakat NTT menganut sistem patrilineal dalam perkawinan. Dalam sistem patrilineal, saudara laki-laki berhak atas tanah warisan orang tua/nenek moyang, juga oleh beberapa etnis, nama marga (klan) hanya dapat diwariskan oleh lakilaki. Di samping itu, dalam praktik hidup harian, perempuan dapat menjalankan peran domestik dengan area gerak hanya seputar rumah dan kebun. Kajian Arivia (2013) mengungkap bahwa di dalam praktik budaya patriarki perempuan adalah makhluk inferior yang tersubordinasi di bawah laki-laki, dan oleh karena itu dia haruslah melakukan sesuatu yang menyenangkan laki-laki, antara lain, yaitu dengan mengasuh anak dengan baik, harus perintah nasehat dan/atau petuah dari ayah dan saudara laki-lakinya, dan lain-lain. Konteks macam itu jugalah yang tergambar di dalam dongeng-dongeng NTT: tokoh perempuan dalam dongeng NTT dikisahkan tunduk dan/takluk pada saudara laki-laki sebagaimana 
tokoh Bete Dou dan Uto Wata yang dikisahkan dalam dongeng asal Belu dan Flores Timur.

Di dalam dongeng-dongeng NTT juga diperlihatkan citra perempuan yang memiliki karakter diri sebagai pribadi yang lemah dan mudah memaafkan orang lain. Hal itu ditunjukkan pada data-data berikut.

(1) Bikuku kemudian dijadikan isteri oleh raja Lakuleik, sedangkan Bita Nahak dijadikan sebagai penjaga kebun... Raka Lakuleik mau tinggal bersama Bita Nahak. Bita Nahak menolaknya, tetapi sia-sia belaka... maka raja Lakuleik menikah dengan Bita Nahak (D2/BN.B/3)

(2) Kire Oli dan Nyona tampak gembira sedang Hera Alure yang diperbudak Ratu menangis sepanjang hari... Hera Alure merasa sangat sakit hati... Kire Oli meminta maaf... mereka hidup rukun dan damai (D7/HA.RS/4)

Dalam dongeng Bita Nahak dan Bikuku (Belu) dikisahkan bahwa Bikuku pernah disakiti oleh Bita Nahak.Hal itu tampak jelas pada kutipan data (D2/BN.B/3). Meskipun demikian, Bikuku tetap menerima Bita Nahak sebagai bagian dari kerajaan meskipun dia hanya menjadi penjaga kebun. Hal ini menggambarkan bahwa Bikuku adalah pribadi yang mudah memaafkan orang lain. Hal yang sama juga diperlihatkan dalam dongeng Hera Alure (Rote-Sabu) yang direpresentasikan melalui tokoh perempuan Hera Alure. Tokoh ini digambarkan memaafkan Kire Oli yang telah menyakit hatinya. Kedua tokoh perempuan dalam dongeng NTT ini merepresentasikan citra perempuan sebagai tokoh yang lemah dan mudah memaafkan orang lain.

Dalam praktik budaya pada hampir tiap entitas NTT, saling memaafkan merupakan praktik budaya. Dalam entitas Dawan, misalnya, memaafkan orang lain, merupakan aktivitas sosial dan budaya. Sebuah upaya rekonsiliasi antara dua pihak yang bersengketa lazimnya dilaksanakan melalui ritual (helas keta) yang melibat dua suku/klan, perempuan dengan perempuan lain, atau perempuan dengan laki-laki, terutama dalam kasus-kasus perkawinan (bdk. Neonbasu, 2016; Nesi, 2018). Dalam kaitan dengan itu dapat dikatakan bahwa dongeng-dongeng NTT sesungguhnya mengisahkan sebuah realitas sosial budaya, terutama ihwal saling memaafkan (rekonsiliasi) antarpihak meskipun di dalam dongeng-dongeng itu upaya rekonsiliasi direpsentasikan melalui tokoh perempuan yang berkarakter "lemah" dan "tunduk".

\section{Citra Perempuan yang Berkaitan dengan Perempuan Lainnya}

Dalam kaitan dengan perempuan lainnya, tokoh perempuan yang dikisahkan di dalam dongeng-dongeng NTT memiliki karakter, yakni (1) bermusuhan atau berselisih, dan (2) memiliki rasa empati. Dalam hal bermusuhan atau berselisih dengan sesama perempuan, dikisahkan di dalam dongeng-dongeng NTT bahwa hal itu terjadi terutama disulut api perselingkuhan. Perempuan yang memiliki suami yang sah pasti bermusuhan dengan perempuan lain yang berselingkuh atau merebut suaminya. Perhatikan data berikut.

(1) Lona Kakapun mulai menyusun siasat untuk menghilangkan nyawa Lona Rara agar dapat merebut suaminya (D4/KLLL.S/3)

(2) Dialah yang sekarang menjadi isteri Kire Oli secara resmi. Hemado Lena sendiri tak dapat berbuat apa-apa karena telah disihir (D7/HA/RS/5)

Sebagaimana dilukiskan dalam Kisah Lona Kaka dan Lona Lara (Sumba), tokoh Lona Kaka terbakar api cemburu lantaran suaminya direbut perempuan lain. Jika dicermati dengan saksama, intervensi tokoh perempuan terhadap kehidupan pribadi atau kehidupan keluarga tokoh perempuan lain dalam dongeng-dongeng NTT digambarkan dapat mengacaukan kebahagiaan atau menyebabkan konflik berkepanjangan (bdk Wonga, 2016). Konflik berkepanjangan itu dapat mengarah pada tindak kekerasan sebagaimana tampak pada data (D4/KLLL.S/3), "Lona Kakapun mulai menyusun siasat untuk menghilangkan nyawa Lona Rara...”. Di sisi lain, di sana digambarkan bahwa menghadapi kasus macam itu, perempuan "menyerah", tidak dapat berbuat apa-apa.

Dalam dongeng Hera Alure, tokoh Hemado Lena tidak dapat mengambil satu pun sikap ketika tokoh perempuan lain, "dia" dijadikan isteri oleh Kire Oli. Hal itu disebabkan Hemado Lena telah disihir oleh Lona Kaka, perempuan kedua yang hadir di di dalam kehidupan privat dan keluarga Hemado Lena. Hal itu tentu saja bukan karena 
Hemado Lena lemah sebagai perempuan melainkan karena faktor lain sebagai penyebabnya, yakni sihir. Adapun sihir merupakan sejenis bentuk mantra, perbuatan ajaib yang dilakukan dengan pesona dan kekuatan gaib (KBBI, 2008). Dalam kehidupan masyarakat primitif, sihir atau mantra merupakan suatu praktik berbahasa yang dampaknya ada di luar akal sehat, dan karena itu dibutuhkan perspektif lintas disiplin untuk dapat menelaahnya secara khusus (Mahmood, 2011; bdk. Neonbasu, 2016b).

Dalam relasi dengan perempuan lain, citra yang juga tergambar pada tokoh perempuan dalam dongeng-dongeng NTT ialah rasa empati sebagaimana ditunjukkan pada data (D4/KLLL.S/4), yakni "Dengan mengajak Nenek Kawena. Nenek Kawena ...berubah menjadi batu. Meski sedih, Nenek Wini tetap meninggalkan kampung".

\section{Citra Perempuan yang Berkaitan dengan Masyarakat}

Selain citra perempuan yang berkaitan dengan perempuan lain, dongeng-dongeng NTT juga mengisahkan tokoh perempuan yang berkaitan dengan masyarakat. Adapun dalam kehidupan bermasyarakat, tokoh perempuan di dalam dongeng-dongeng NTT memiliki beberapa citra, yakni (1) bersikap kesatria dan rela berkorban, dan (2) ingin mendapatkan pengakuan. Citra ksatria tokoh perempuan dalam dongeng NTT ditemukan pada data-data berikut.

(1) Uto diminta untuk menjadi istri Nitung (hantu penghuni mata air itu)... Uto ternyata mau menerima lamaran Nitung. Mereka mendapatkan air yang melimpah ruah. Janji Nitung ditepati (D4/UW.FT/3)

(2) Sang Raja dan permaisuri berharap Putri akan membawa berkah untuk kesejahteraan kerajaan dan seluruh rakyatnya. ...mereka berniat untuk memingit sang Putri agar kesuciannya tetap terjaga. Mulanya, sang Putri menolaknya. ...akhirnya iapun bersedia pindah ketempat tinggal barunya itu $(\mathrm{D} 2 / \mathrm{BD} / \mathrm{B} / 3)$

Pada data (D4/UW.FT/3) yang dikutip dari dongeng Kisah Uto Wata (Flores Timur), tokoh perempuan, Uto, bersedia menjadi isteri Nitung. Adapun Nitung adalah "hantu penghuni mata air".
Dalam kebanyakan mitos NTT, dan Flores Timur khususnya, beredarnya mitos tentang "penjaga mata air" dapat digambarkan sebagai sosok yang berwujud hantu, dan kadangkala juga dapat diyakini sebagai sosok yang berkenaan dengan asal-usul nenek moyang (bdk. Taum, 1997). Dalam konteks seperti itulah, tokoh Uto dalam dongeng itu digambarkan sebagai pribadi yang ksatria karena ia berani dan menerima menjadi istri dari sosok yang bukan manusia biasa. Adapun dalam masyarakat, tokoh perempuan digambarkan memegang peran penting dalam "istana kerajaan" sebagaimana ditunjukkan pada data ((D2/BD/B/3)). Sebagai dongeng, dunia yang digambarkan menampilkan tokoh-tokoh perempuan yang memiliki sikap ksatria, bahkan dalam hal mempertahankan wilayah kerajaan. Citra ini juga berkaitan dengan citra perempuan yang ingin mendapatkan pengakuan dari masyarakat sebagaimana terlihat pada data-data berikut.

(1) Seluruh warga terheran-heran melihat kedatangannya. Apalagi ia datang bersama dengan seorang pemuda yang gagah dan tampan. Sambil tersenyumsenyum, Lona Rara berjalan disamping suaminya menuju kerumahnya. Bersedia pindah ketempat tinggal barunya itu (D4/KLLL.S/5)

(2) "Sekarang kita akan memasuki istana. Jadi engkau harus memberikan kainmu kepada saya, dan sebagai gantinya engkau memakai sokal (D6/BD.B/1)

(3) Kabar tentang peminangan dimakluminya. Oleh sebab itu ia bermaksud akan memperlengkapkan dirinya dengan bermacam-macam keterampilan seperti tenun-menenun, teknik ikat motif, dan teknik celupcepupan(D7/HA.RS/6)

Pada data (D4/KLLL.S/5), (D6/BD.B/1), dan (D7/HA.RS/6) digambarkan mengenai citra tokoh perempuan yang ingin mendapatkan pengakuan dari masyarakat. Wujud pengakuan yang diinginkan para tokoh perempuan dalam dongengdongeng NTT ialah mereka ingin memiliki pasangan hidup yang serasi, tampan, dan berwibawa (data 1 dan 2), serta mereka ingin dihargai atau diakui karena profesi atau pekerjaan mereka seperti menyulam, celup-celupan, dan menenun. (data 3). Citra macam itu tentu tidak 
terlepas dari kebutuhan psikologis perempuan untuk memperoleh pengakuan sosial.

\section{Simpulan}

Dalam dongeng-dongeng NTT teridentifikasi 4 (empat) citra tokoh perempuan, yakni (1) citra perempuan yang berkaitan dengan dirinya sendiri, (2) citra perempuan yang berkaitan dengan laki-laki, dan (3) citra perempuan yang berkaitan perempuan lainnya, (4) citra perempuan yang berkaitan dengan masyarakat. Dari keempat citra itu diidentifikasi pula karakter tokoh perempuan dalam dongengdongeng NTT, yakni mereka adalah pribadi mandiri, pekerja keras, pemberani, memiliki keahlian/keterampilan tertentu, pribadi spiritual (makhluk religius), dan mampu melakukan kekerasan. Tokoh perempuan dalam dongengdongeng NTT juga memiliki citra Tidak ingin dijajah secara seksual atau mandiri dalam memilih pasangan, takhluk pada saudara laki-laki, dan lemah dan mudah memaafkan orang lain. Di sisi lain, mereka juga digambarkan berkarakter bermusuhan, berselisih, merebut suami orang lain, memiliki rasa empati, bersikap kesatria dan rela berkorban, serta ingin mendapatkan pengakuan sosial dari masyarakat.

\section{Daftar Pustaka}

Arivia, G. (2003). Filsafat Berperspektif Feminis. Jakarta: Yayasan Jurnal Perempuan.

Cresswel, J. W. (2010). Research Design: Pendekatan Kualitatif, Kuantitatif, dan Mixed. Yogyakarta: Pustaka Pelajar.

Danandjaja, J. (2015). "Pendekatan Folklor dalam Penelitian Tradisi Lisan" dalam Pudentia (eds.) Metodologi Kajian Tradisi Lisan. Jakarta: Yayasan Pustaka Obor Indonesia.

Duija, I. N. (2005). "Tradisi Lisan, Naskah, dan Sejarah: Sebuah Catatan Politik Kebudayaan" dalam Wacana, 7(2), 111124.

Forshee, J. (2006). Culture and Customs of Indonesia. London: Greenwood Press.
Mahmood, S. (2011). "Religion, Feminism, and Empire: The New Ambassadors of Islamophobia" dalam Linda Martín Alcoff and John D. Caputo (eds.). Feminism, Sexuality and the Return of Religion. Bloomington: Indiana University Press.

Neonbasu, G. (2016a). Citra Manusia Berbudaya: Sebuah Monografi tentang Timor dalam Perspektrif

Neonbasu, G. (2016b). Akar Kehidupan Masyarakat Sumba dalam Citra Marapu. Jakarta: Lappop Press bekerja sama dengan Unika Widya Mandira.

Nurgiyantoro, B. (2007). Teori Pengkajian Fiksi. Cetakan ketiga. Yogyakarta: Gadjah Mada University Press.

Ratna, K. N. (2011). Antropolgi Sastra Peranan Unsur-Unsur Kebudayaan dalam Proses Kreatif. Yogyakarta: Pustaka Pelajar.

Riffaterre, M. (1978). Semiotics of Poetry. London: Metheun \& Co. Ltd.

Sangidu. (2004). Penelitian Sastra: Pendekatan, Teori, Metode, Teknik, dan Kiat. Yogyakarta: Unit Penerbitan Sastra Asia Barat Fakultas Ilmu Budaya Universitas Gadjah Mada.

Walby, S. (2011). The Impact Feminism on Sociology. Sociological Reseach Online, 16(3), 1-10.

Pusat Penelitian Wanita Undana. (2000). Hak Asasi dan Kekerasan Terhadap Perempuan. Kupang: Undana.

Sakina, A. I. ( 2017). "Menyoroti budaya patriarki di indonesia." Share: Social Work Journal, $7(1), 71-80$.

Soewadji, J. (2012). Pengantar Metodologi Penelitian. Jakarta: Mitra Wacana Media

Sudaryanto. (2015).Metode dan Teknik Analisis Bahasa: Pengantar Penelitian Wahana Kebudayaan secara Linguistis. Yogyakarta: Sanata Dharma University Press. 
Sudikan, S. Y. (2013). "Kearifan Lokal dalam Tradisi Lisan Nusantara: Penggalian Nilainilai Kebhinekaan untuk Indonesia Masa Kini dan Masa Depan" dalam Endraswara, S. (eds.). Folklor Nusantara: Hakikat, Bentuk, dan Fungsi. Yogyakarta: Ombak.

Sugihastuti. (2000). Wanita di Mata Wanita. Bandung: Nuansa.

Sofia, A. (2009). Aplikasi Kritik Sastra Feminis. Yogyakarta: Citra Pustaka

Taum, Y. Y. (2011). Studi Sastra Lisan Sejarah, Teori, Metode dan Pendekatan, Disertai
Contoh Penerapannya. Yogyakarta: Penerbit Lamalera.

Taum, Y. Y. (1997). Kisah Wato Wele-Lia Nurat. Jakarta: Yayasan Obor Indonesia \&Yayasan Asosiasi Tradisi Lisan.

Wiyatmi. (2009). Pengantar Kajian Sastra. Yogyakarta: Pustaka Book Publisher.

Wonga, D. (2016). Citra Perempuan dalam Kumpulan Cerita Rakyat Flores Timur Lamaholot. Yogyakarta: Prodi Bahasa Dan Sastra Indonesia, UNY 5(4). 